\title{
硫酸液滴の付着量が純鉄表面の腐食挙動に及ぼす影響
}

\section{王栄光 木戸光夫鈴村文寛向井弘治}

広島工業大学工学部機械システム工学科

J. Japan Inst. Metals, Vol. 70, No. 11 (2006), pp. 929-935

(C) 2006 The Japan Institute of Metals

\section{Influence of Droplet Volume of Sulfuric Acid Solution on Corrosion Behavior of Pure Iron}

Rongguang Wang, Mitsuo Kido, Fumihiro Suzumura and Koji Mukai

Department of Mechanical Systems Engineering, Faculty of Engineering, Hiroshima Institute of Technology, Hiroshima 731-5193

The volume influence of aqueous sulfuric acid solution on the corrosion rate of pure iron during the initial $0.6 \mathrm{ks}$ was investigated by potentiostat, digital microscope and atomic force microscope (AFM). Three types of solution volume on the specimen, bulk solution, macro-droplet with millimeter size and micro-droplet with micrometer size, were used.

A micro-droplet with diameter of $1 \sim 10 \mu \mathrm{m}$ can be produced on a pre-assigned target micro-zone of specimen by the cantilever tip of AFM. The corrosion behavior by the droplet can be investigated using both the contact mode and the AC non-contact mode of AFM. The corrosion rate in bulk solution was much higher than that in a micro-droplet of sulfuric acid solution. In the case of corrosion on pure iron surface caused by a micro-droplet, the corrosion rate was smaller for the smaller droplet. The solidification of the micro-droplet in $25-30 \% \mathrm{RH}$ condition is faster than that in $50-70 \% \mathrm{RH}$ condition.

(Received May 30, 2006; Accepted September 6, 2006)

Keywords: iron, corrosion, sulfuric acid, droplet, volume of solution

\section{1. 緒言}

近年, マイクロマシーンや電子デバイスの高密度化・高速 度化が進み，その金属配線の幅は数 $10 \mathrm{~nm}$ にもってい る1).こうした微細な部分にマイクロおよびナノサイズのミ クロな水滴(膜)が凝着すると, 大気中の $\mathrm{O}_{2}, \mathrm{CO}_{2}, \mathrm{SO}_{x}$ およ び $\mathrm{NO}_{x}$ などが吸着されやすくなり，それによって生ずる僅 かな腐食損傷がシステム全体の稼働性や安全性に多大な影響 を及ぼす恐れがある。したがって，材料の表面改質や微小部 品の構造設計には, ミクロな液滴の付着による腐食挙動を解 明して抢くことが重要である. 一方, 約 $10 \sim 100 \mu \mathrm{m}$ の平均 膜厚の $\mathrm{Na}_{2} \mathrm{SO}_{4}$ または $\mathrm{NaCl}$ 各水溶液で, 炭素鋼, 低合金鋼 または銅の大気腐食速度が最大になることが，腐食反応に伴 う酸素の消費速度やインピーダンスなどの測定によって明ら かにされている2-4). しかし，ミクロな液滴によって生ずる 腐食は, 液滴そのものの観察・測定が困難であるため, 直接 的に調べた例はきわめて少ない.

近年, $\mathrm{Hu}^{5)}$, 升田 ${ }^{6,7)}$ および著者 $5^{8-10)}$ は, 原子間力顕微鏡 の静電気ノンコンタクトモードまたは ACノンコンタクト モード (振動モード)を用いて, 固体表面に付着しているミク ロな液滴の観察に成功した。これによると, 大気中でのミク ロな水滴はマクロな水滴に比べて蒸発しにくく, 比較的長時 間安定していることおよび需れ接触角は小さいことがわかっ た ${ }^{8-10)}$. そこで著者らは, この観察手法を利用して, 硫酸溶 液のミクロな液滴をステンレス鋼表面に多数付着させ, それ による腐食挙動を調査し報告してきた ${ }^{11)}$. その結果, 数多
くの腐食形態が観察・確認されたものの, 腐食速度に対して 液滴寸法がどのような影響を及ぼすかについてはほとんど不 明である。

そこで本研究では, 原子間力顕微鏡 $(\mathrm{AFM})$ を用い, 純鉄 表面の任意の箇所へのミクロな硫酸液滴の付着を試みたの ち, その連続的観察を行い, ミクロな硫酸液滴による腐食挙 動の変化を調べた. また, 比較として, 同様形状 ·寸法の純 鉄試験片が硫酸水溶液中に浸漬された場合の浸漬腐食速度お よびマクロな硫酸液滴(ミリサイズ)の付着による腐食様相の 2 点を調べた．以上のことより，硫酸水溶液の付着量が金属 の腐食挙動に及ぼす影響について種々検討を行った。

\section{2. 実 験 方 法}

供試材は，市販の純鉄 (純度 $99.8 \%$ ) 板材であり，それを $15 \mathrm{~mm} \times 15 \mathrm{~mm} \times 2 \mathrm{~mm}$ の正方形状板に加工後, $15 \mathrm{~mm} \times 15$ $\mathrm{mm}$ の片側面を＃1200のエメリー紙で乾式研磨後, アルミ ナ粉末 (平均粒径 $0.05 \mu \mathrm{m}$ ) でバフ仕上げを行い試験片とし た. なお, すべての試験片とも, 試験前にアセトン中で脱脂 洗滌させ, その後温風乾燥を行っている. 腐食実験に使用し た水溶液は, 5 mass\%の希硫酸水溶液である.

水溶液 $(500 \mathrm{~mL})$ 中に自然浸漬したものの腐食速度は, ポ テンショスタット(北斗電工侏製 $\mathrm{HA}-303$ )を用いて, 白金板 を対極, 飽和カロメル電極(S.C.E.)を照合電極とした 3 電極 方式により, カソード抢よびアノード分極曲線を硫酸水溶液 中で測定し, ターフェル外插法によって算出した. また, 試 験片を硫酸水溶液に約 $0.6 \mathrm{ks}$ 間浸漬させた後, 表面観察お 
よび重量測定 (島津製作所侏製 BX3200H)を行った。表面観 察には，デジタルマイクロスコープ(Keyence Corporation侏 製；以下 DM と略称する)を用いた。

マクロな液滴の付着による腐食様相は，まずマイクロピペ ットを用いて希硫酸水溶液( 約 $5 \mu \mathrm{L}\left(5 \times 10^{9} \mu \mathrm{m}^{3}\right)$ ) を試験片 表面に滴下させ，その液滴の断面形状の経時变化を DM に よって調べた。なお，比較として，同様な実験を純水でも行 った，次に，表面を純水执よ゙アセント中で洗滌した後，そ の観察をDMによって行った.

ミクロな液滴の付着による腐食様相は，原子間力顕微鏡 (Atomic Force Microscope，島津製作所侏製 SPF-9800； $\mathrm{AFM})$ の $\mathrm{AC}$ ノンコンタクトモードおよびコンタクトモード を併用させて調べた．AFM には，先端曲率半径が約 $10 \mathrm{~nm}$ のカンチレバー(シリコン製)を用いた．液滴の付着および観 察法方を Fig. 1 に示す。まず，（a）事前観察によって，液滴 を付着しようとする場所をあらかじめ決定し，観察領域の中 心座標抢よび表面の三次元形態を記録して抢く，次に，(b) あらかじめ試験片に隣接させておいたガラス板表面に，希硫 酸水溶液の薄い液膜を張り，この液膜にカンチレバー先端を 接触させ，それに液滴を付着させた。 その後，（c）あらかじ め決定しておいた試験片表面の所定位置にカンチレバーを移 動させ，先端の液滴をその位置に付着させた．さらに，(d) 付着した液滴とその周辺付近を $\mathrm{AC}$ ノンコンタクトモードに よって連続的に観察し，ミクロな液滴形状の経時变化を調べ た、 ACノンコンタクトモードの特徵は, カンチレバー先端 と液滴との間に㗢く力がかなり小さいので, 液/固界面では なく，液滴の表面のみを観察できることである ${ }^{8-10)}$. (e) 液 滴が表面に付着してから所定時間を経過後，モードをコンタ クトモードに切り換え液滴とその周辺を走査させ，付着した ミクロな硫酸液滴による腐食様相を調査した。コンタクト モードの特徵は, カンチレバー先端と液滴との間に働く力が $\mathrm{AC}$ ノンコンタクトモードの場合よりもはるかに大きいの で，カンチレバー先端は液滴の中に入り込んでしまい液/固 界面が観察できることである ${ }^{8-10)}$. 以上， $(\mathrm{a}) \sim(\mathrm{e})$ の各実験

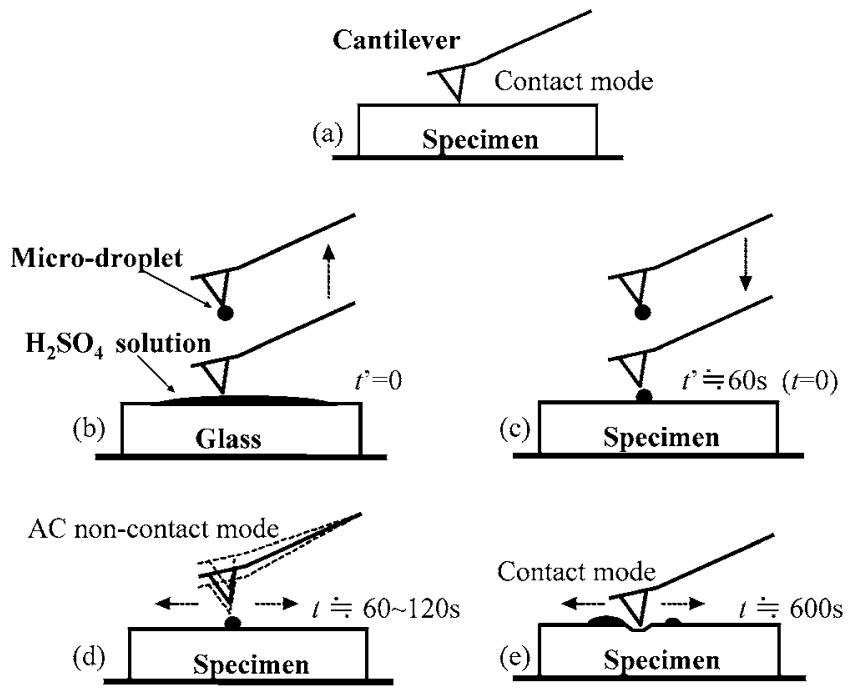

Fig. 1 Procedure of putting a micro-droplet of $\mathrm{H}_{2} \mathrm{SO}_{4}$ solution on specimen surface and investigating the corrosion behavior of specimen beneath the droplet.
とも，室温が $296 \pm 3 \mathrm{~K}$ ，相対湿度が $50 \sim 70 \% \mathrm{RH}$ または 25 〜30\%RH の大気中で行った.

\section{3. 実験結果および考察}

\section{1 水溶液中に自然浸漬した場合の腐食速度}

Fig. 2 は，水溶液 $\left(5 \% \mathrm{H}_{2} \mathrm{SO}_{4}\right)$ に純鉄 $(\mathrm{Fe})$ を $0.6 \mathrm{ks}$ 間自然 浸漬させた表面をDM によって観察したものである。これ によると, 試験片は全面が腐食を起こしており, とくに優先 的に腐食した表面には小さなピット (以下，腐食痕)が多く観 察されている. 一方, 同様な水溶液下で得られた Fe の分極 曲線から，ターフェル外挿法を適用して導出した腐食電流密 度 (3 回測定による平均值) $i_{\text {corr. }}$ を用いて腐食速度を計算する と，約 $0.05 \mathrm{~nm} / \mathrm{s}$ であった。

\section{2 マクロな液滴付着による腐食様相}

Fig. 3 は，湿度が 25〜30\%RH および 50〜 70\%RH の環 境中で付着した純水抢よび $5 \% \mathrm{H}_{2} \mathrm{SO}_{4}$ 水溶液のマクロな液滴 の濡れ接触角 (5 回測定したものの平均值)の経時变化を示し たものである。これによると，いずれの場合も，液滴が試験 片表面に付着後, 時間経過に伴ってその体積は減少（水分の 蒸発によって減少) し, 濡れ接触角 $\theta$ は小さくなっている. また，純水に比べ，希硫酸の場合は，高湿度・低湿度ともに 短時間で接触角 $\theta$ は小さくなっている。これは, 後記の Fig. 4 に示す腐食痕の生成によって Fe の表面積が変化し, さらに腐食生成物が $\mathrm{Fe}$ 表面のエネルギーを増加させたため と考えられる。

Fig. 4 は，液滴付着によって $0.6 \mathrm{ks}$ 間腐食した，Fe 表面 の DM 写真である。これによると，高湿度・低湿度下とも に水溶液中に自然浸漬した場合のそれと似ており, 全面腐食 や小さな腐食痕が観察されている。すなわち，試験片表面に 付着する水溶液が多い場合，固/液界面状態のバラツキによ って個々の部分がアノードとカソードに分離し，アノード部 のみが腐食され，そこで小さな腐食痕が生成することは明ら かである。

高湿度下に比べ低湿度下では，小さな腐食痕が多く観察さ れた。これは， $296 \mathrm{~K}$ の場合， $\mathrm{H}_{2} \mathrm{SO}_{4}$ 水溶液の平衡濃度が 相対湿度 $30 \% \mathrm{RH}$ で 43.6 mass \%，湿度 $60 \% \mathrm{RH}$ で 38.9 mass\%であること的関係しているものと考えられる。す

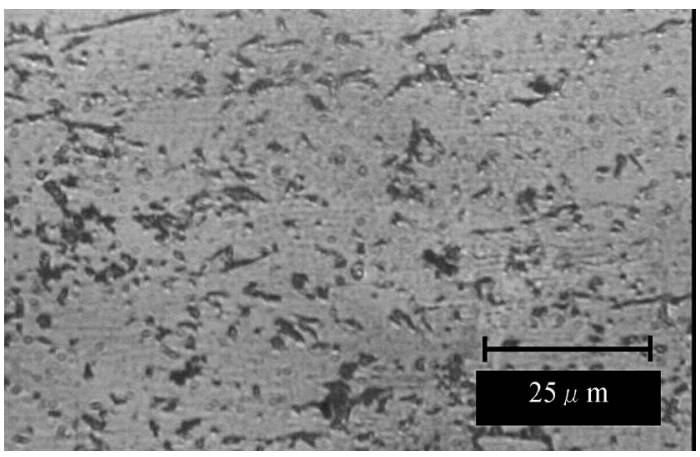

Fig. 2 Surface morphologies of specimen after immersion corrosion in 5 mass $\% \mathrm{H}_{2} \mathrm{SO}_{4}$ solution by a digital microscope. 
なわち, 湿度が低いと $\mathrm{H}_{2} \mathrm{SO}_{4}$ 水溶液中での平衡濃度が高い ので，水分蒸発によって液滴の実際濃度が相対的に高くな り，腐食痕の形成速度が顕著であるものと考えられる。一 方， $43.6 \%$ と $38.9 \%$ の $\mathrm{H}_{2} \mathrm{SO}_{4}$ 水溶液を用いて同様な液滴に よる腐食実験を行ったところ，試験片表面には，小さな腐食 痕ではなく結晶粒界が観察・確認された。したがって, $5 \% \mathrm{H}_{2} \mathrm{SO}_{4}$ 水溶液のマクロな液滴は湿度の違いによって濃度 に変化はあるものの, 平衡濃度に示される程の高濃度には变 化して抢らす，多少，水分の蒸発速度に差が出る程度のもの であると考えられる。

\section{3 ミクロな液滴付着の AFM による観察}

Fig. 5 は，前記 Fig. 1 に示した手順によって Fe 表面の任 意の場所にミクロな硫酸液滴 $\left(5 \% \mathrm{H}_{2} \mathrm{SO}_{4}\right.$ 水溶液)を付着さ
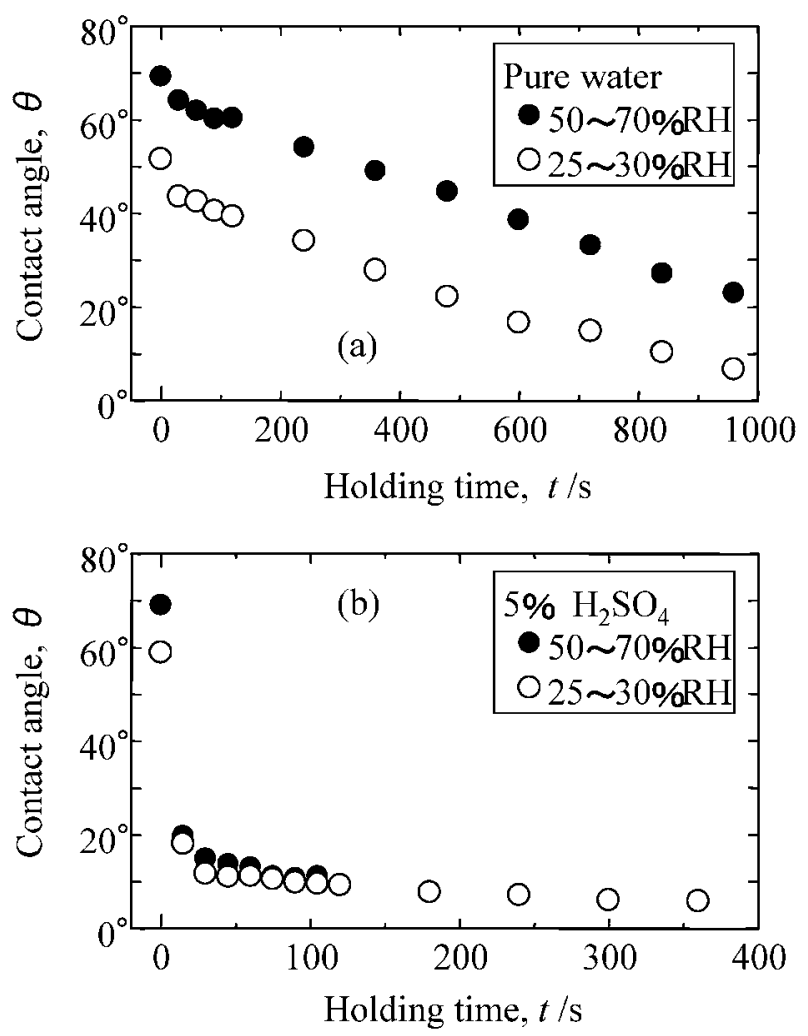

Fig. 3 Contact angle of macro-droplet of pure water (a) and 5 mass $\% \mathrm{H}_{2} \mathrm{SO}_{4}$ solution (b) on pure iron surface with holding time.
せ，その形態の連続観察を試みた一例(高湿度環境中)である. Fig. 5 (a) は液滴を付着させる前の Fe 表面であり，同図 (b) は液滴を AFM で所定の場所に約 $0.18 \mathrm{ks}$ 付着させた後, $\mathrm{AFM}$ の ACノンコンタクトモードで観察したものである. 同図 (c) は (b) と同じ場所を $1.2 \mathrm{ks}$ 後 AFM のコンタクト モードによって観察したものである。（b)で見られた突起物 は，(a)では全く見られず，また突起物とその周辺部をコン タクトモードで走査したところ, 突起物は消失した (図 (c) 参 照)ため，この突起物は液滴であると断定できる ${ }^{8)}$. 以上よ り， AFM のカンチレバーを用いると $\mathrm{Fe}$ 表面の任意の場所 へのミクロな硫酸液滴の付着およびその場連続観察が可能で あることがわかった，また，走査モードをコンタクトモード に切り換えることによって, 液滴付着による材料表面の腐食 様相も観察できることがわかった.

\section{4 ミクロな硫酸液滴付着による腐食様相}

Fig. 6 は，ミクロな硫酸液滴の付着様相を低湿度下で観察
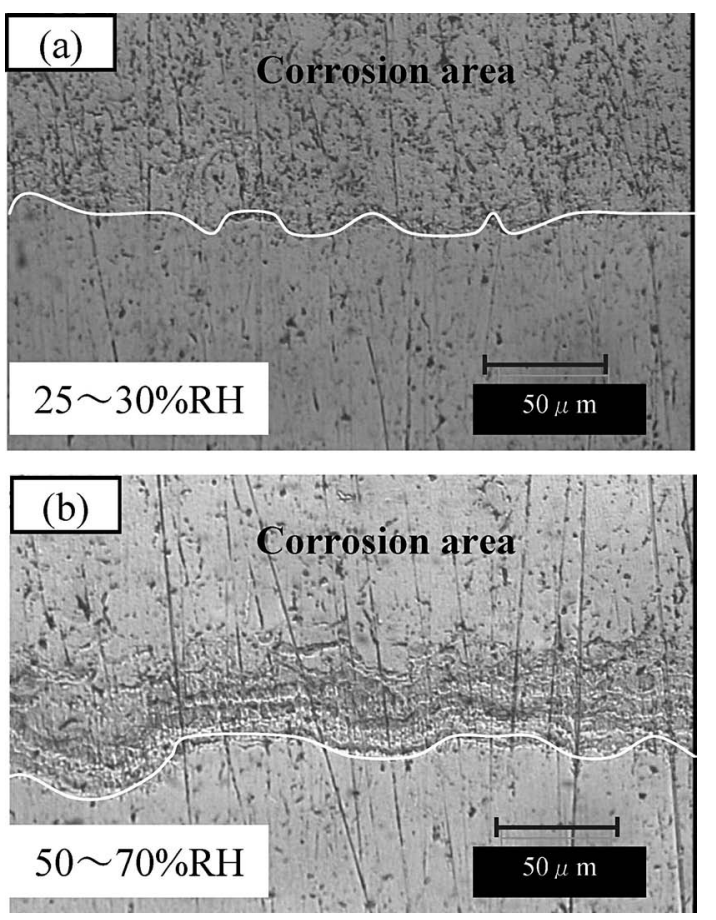

Fig. 4 Surface morphologies after corrosion by a macrodroplet of 5 mass $\% \mathrm{H}_{2} \mathrm{SO}_{4}$ solution in $25 \sim 30 \% \mathrm{RH}$ (a) and 50 $70 \% \mathrm{RH}(\mathrm{b})$ ambient air.
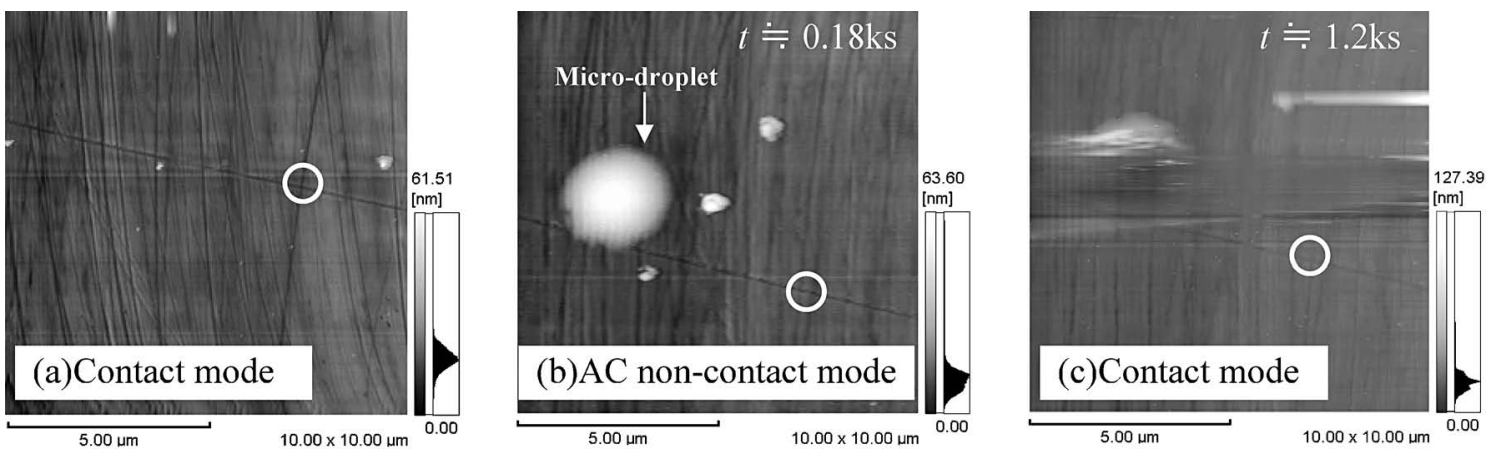

Fig. 5 An observation result of producing a micro-droplet of $\mathrm{H}_{2} \mathrm{SO}_{4}$ on pure iron surface and removing it by scanning of the cantilever. (a) pre-assigned micro-zone, (b) a micro-droplet on this zone, (c) the droplet has been removed by cantilever. 
した代表的な結果である. 液滴が付着する前の $\mathrm{Fe}$ の表面様 相は省略しているが，同図 $\left(\mathrm{a}_{1}\right) \sim\left(\mathrm{a}_{3}\right)$ は液滴付着後に $\left.\mathrm{AC}\right)$ ンコンタクトモードによって観察したもの, 図 $\left(\mathrm{b}_{1}\right) \sim\left(\mathrm{b}_{3}\right)$ は 液滴の付着後 $0.6 \mathrm{ks}$ 間経過した液滴とその周辺部をコンタ クトモードにより観察した AFM 写真である。これによる と, 試験片表面に球冠状の液滴が付着した形態や液滴周囲に 薄い液膜が広がった形態さらに液滴周囲に微小な液滴を有し たものなどが観察された. 高湿度環境中でも, 同じ様相が再 三観察された。これは，カンチレバーに付着した液滴の量や その先端と試験片との接触動作に関連している可能性が考え られるが，詳細については現在のところ不明である．液滴付 着から $0.6 \mathrm{ks}$ を経過した後にコンタクトモードによって走 査したところ，いずれの場合も完全に液滴を除去することが できなかった。これは，液滴と基材間の腐食反応によって腐 食生成物が生成し，それが液滴内に堆積して液滴の形状に固 化したため11) と考えられる．以上の観察結果から， Fe 表面 に付着したミクロな硫酸水液滴による腐食は，マクロなそれ とはかなり異なることがわかる。

Fig. 7 は，高・低湿度下でのミクロな液滴の付着様相 (a)

(a) AC non-contact mode
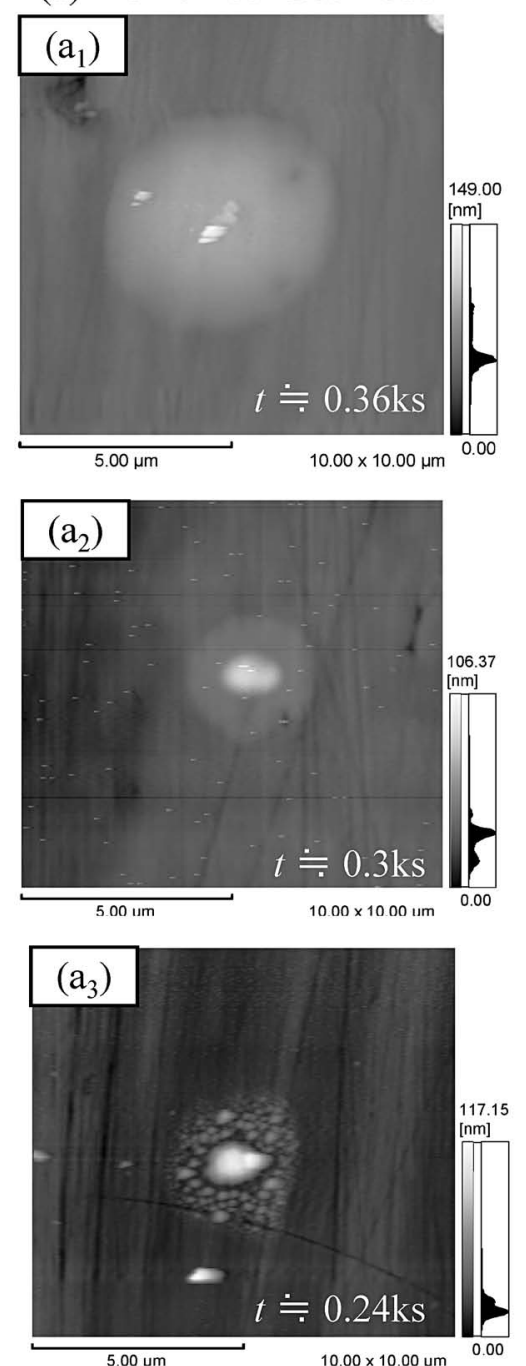

$10.00 \times 10.00$ um 0.00
およびそれより $0.6 \mathrm{ks}$ を経過した後コンタクトモードを用

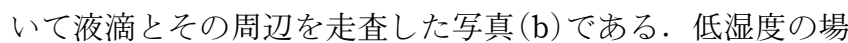
合とは異なり，液滴が付着した基材の $\mathrm{Fe}$ に窪みが観察され た (c).これは, 硫酸液滴に接触する試験片の表面が腐食反 応によって溶解して形成されたと考えられる，また，高湿度 下で液滴付着後，それぞれ約 $1.8 \mathrm{ks} ， 2.4 \mathrm{ks}$ および $3.0 \mathrm{ks}$ 経 過した後に同様な調查を行った結果を Fig. 8 に示す。高湿 度下では液滴付着より約 $2.4 \mathrm{ks}$ までは，その液滴の除去は 可能であったが， $3.0 \mathrm{ks}$ を経過するとその除去はできなくな り，付着時間の増加と共に，液滴の除去は困難になることが わかった．液滴が完全に固化するまでの時間の比較から，低 湿度の場合より高湿度の場合の方が Fe の腐食速度は低い可 能性が考えられるが，これについてさらなる確認が必要であ る.

Fig. 9 は，ミクロな硫酸液滴を高湿度下で付着させ，それ ぞれ約 $0.3 \mathrm{ks}, 1.8 \mathrm{ks}, 5.4 \mathrm{ks}$ および $10.2 \mathrm{ks}$ 経過後にその様 相を観察した結果 (一例)である. 液滴付着から約 $3.0 \mathrm{ks}$ 経 過後(図略)に, 液滴の中心部は窪み, さらに約 $5.4 \mathrm{ks}$ 経過 後には，その窪みがはっきりと現れている。“液滴”は液体
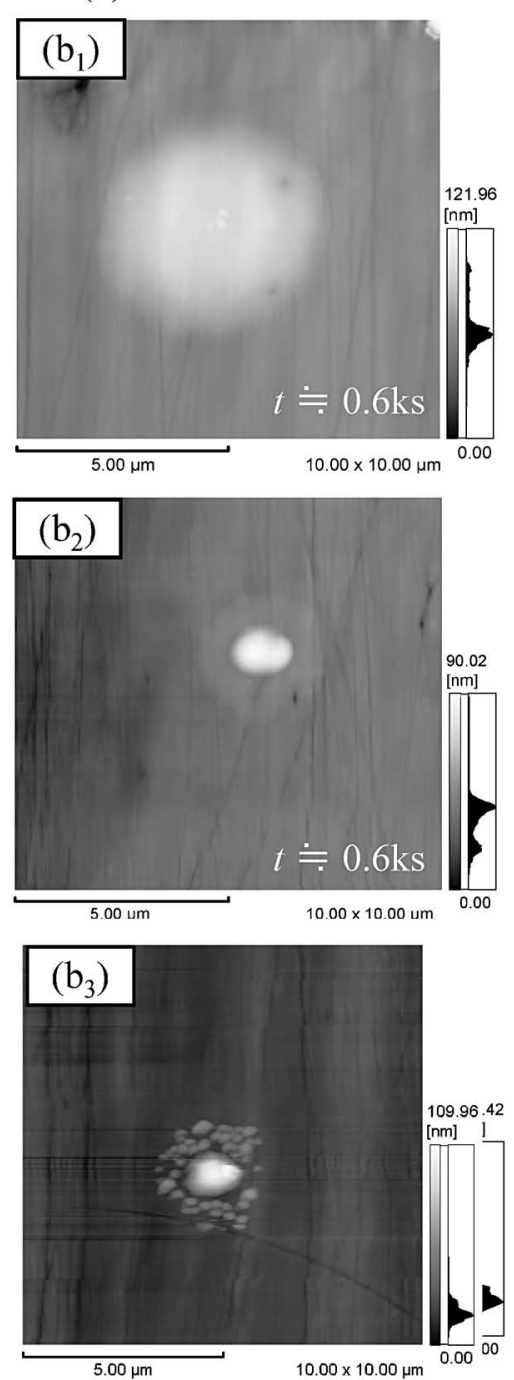

Fig. 6 Representative patterns of produced micro-droplet of $\mathrm{H}_{2} \mathrm{SO}_{4}$ solution on pure iron surface and their solidification within 0.6 $\mathrm{ks}$ in $25-30 \% \mathrm{RH}$ ambient air. 
のままでその中心部が寉むとは考えにくいので，これは，腐 食生成物が堆積し液体から固体に近い状態へと変化したとき に生じたものと考えられる。この現象は， $\mathrm{MgCl}_{2}$ 水溶液の
微小液滴を低合金鋼に付着したときにも生じており, 液滴直 下でアノード溶解が先行して生じている13)ためと考えられ る.
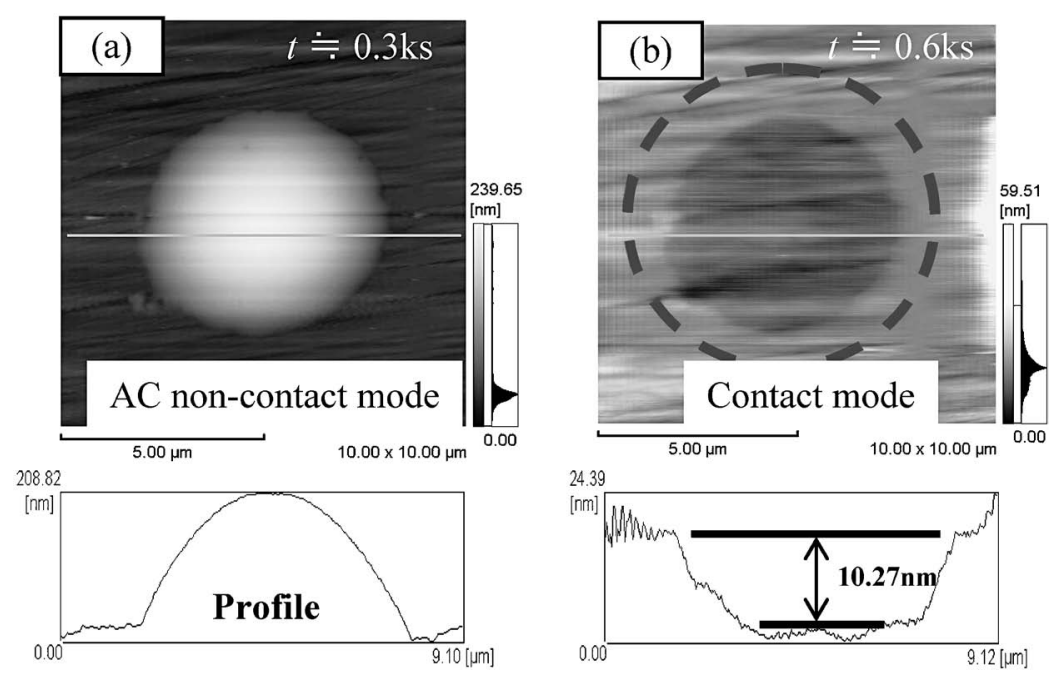

Fig. 7 Specimen surfaces and profiles after corrosion by a micro-droplet of $\mathrm{H}_{2} \mathrm{SO}_{4}$ for a period of $0.6 \mathrm{ks}$.

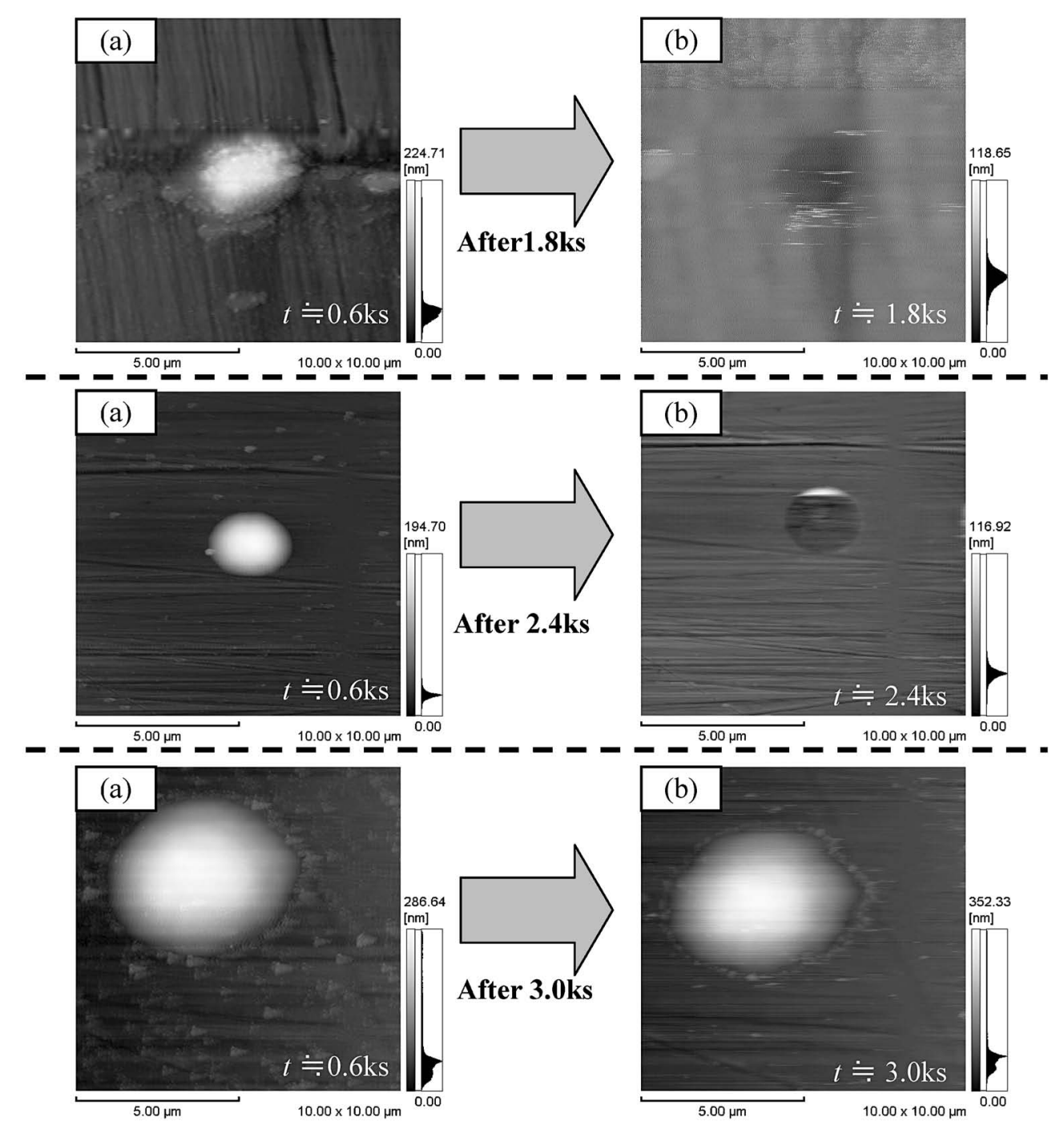

Fig. 8 Representative patterns of micro-droplets of $\mathrm{H}_{2} \mathrm{SO}_{4}$ solution with different holding time in $50 \sim 70 \% \mathrm{RH}$ ambient air. 
Fig. 10 は，付着した液滴の体積と接触角の経時変化を連 続観察したその一例である。これから明らかなように，ミク ロな硫酸液滴の体積および接触角とも低湿度下ではほとんど 変化していない。これは, 既にFig. 6 で示したように, 液 滴が固体へ短時間で変化したことに対応している. 一方, 高 湿度下では, 液滴が付着した時点からその体積は徐々に増加 する傾向になり，その後は低下してほぼ一定になった。こう した液滴体積が増加する傾向は, 高湿度下の実験で数多く観 察されて抢り，おそらく大気中の水分が液滴に吸収されたた めと考えられる．マクロな液滴に比べてミクロなそれは，表 面積/体積比率がはるかに大きく, しかもその表面曲率半径 が著しく小さい。一般に, 液滴の曲率半径が小さい程その飽 和蒸気圧は高い14).このことから, 大気中でのミクロな水 分の蒸発速度はマクロのそれより速いものと考えられる. ま た，ミクロな液滴はガラス板上の液膜から $\mathrm{Fe}$ 表面に付着し さらに AFM による観察が始まるまでの所要時間が約 0.06 〜 $0.12 \mathrm{ks}$ である.この間に, AFM のカンチレバー先端に 付着したこの液滴は, 早急に平衡濃度へと濃縮する可能性が ある.したがって，ミクロな硫酸液滴が $\mathrm{Fe}$ 表面に付着した 時点では(または少なくとも観察が始まった時点では)，すで に平衡濃度付近に濃縮したものと推測される. その後, 体積 の増加抢よび減少は, 腐食反応に伴う平衡濃度の微小変化に よって，水分が蒸発したことによるものと考えられる．これ については, 直接, ミクロな液滴濃度の測定が困難なので, 今のところ不明な点は多い。接触角 $\theta$ は, 時間経過に伴い若 干上昇する傾向が認められたが，マクロな濡れの場合のよう に大きな変化は認められなかった。これは $\mathrm{Fe}$ 表面において は，ミクロな液滴の腐食による表面変化がマクロの場合のそ れ程大きくないことを示唆している。

\section{5 腐食速度の水溶液付着量の違いによる変化}

各付着量のもとで測定した，5\%硫酸水溶液による腐食速
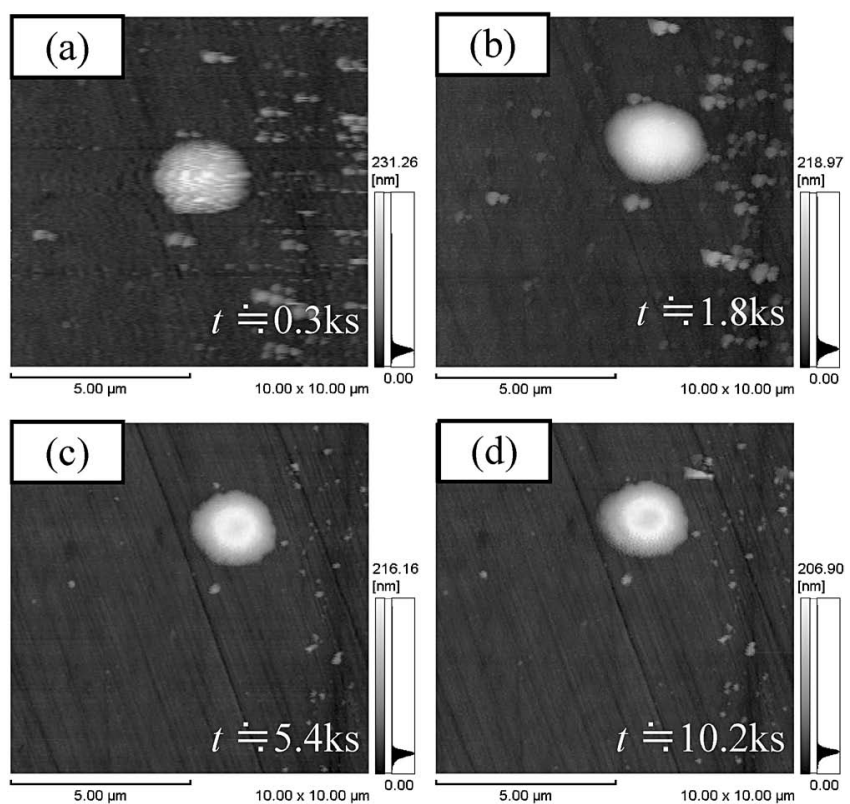

Fig. 9 Representative patterns of micro-droplets of $\mathrm{H}_{2} \mathrm{SO}_{4}$ with holding time observed by $\mathrm{AC}$ non-contact mode.
度 (腐食時間：0.6 ks)ををとめたのが Fig. 11 である。ま た，ミクロな液滴は実際に水分の蒸発によって平衡濃度の濃 硫酸になる可能性を考慮して，平衡濃度の濃硫酸による水溶 液中の腐食速度も測定し同図に示してある.これによると， ミクロな液滴による腐食速度は，水溶液中よりはるかに小さ
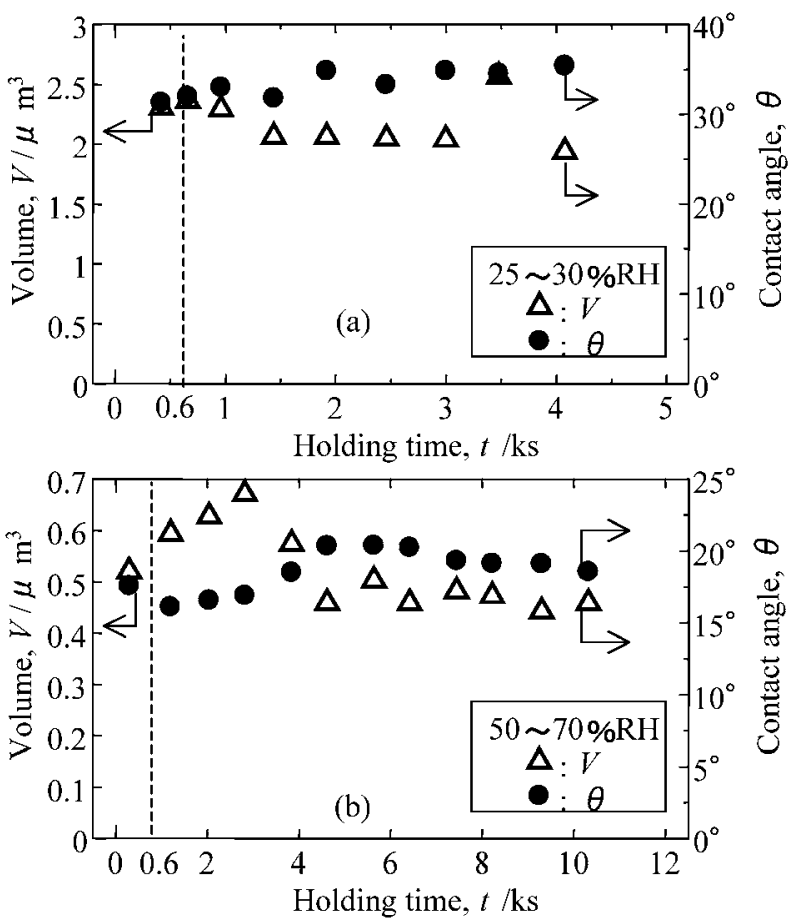

Fig. 10 Contact angle and volume change of a micro-droplet of $\mathrm{H}_{2} \mathrm{SO}_{4}$ solution with holding time in $25 \sim 30 \% \mathrm{RH}$ (a) and 50 $\sim 70 \%$ RH (b) ambient air.

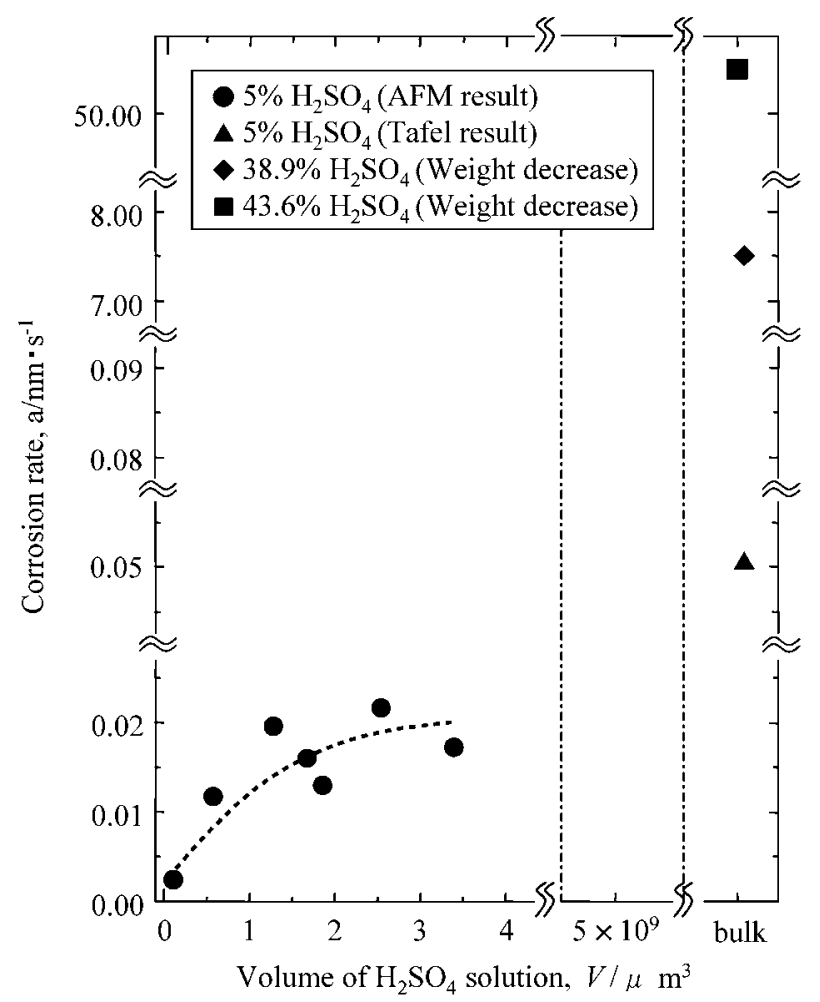

Fig. 11 Corrosion rate of pure iron by different volumes of $\mathrm{H}_{2} \mathrm{SO}_{4}$ solution. 
くなっている，また，ミクロな液滴の場合は，液滴の体積が 小さい程腐食速度も小さい.

\section{6 腐食速度と水溶液量との関係}

微小な液滴による腐食は, 一般に湿り大気腐食のモデ

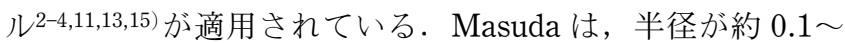
$0.2 \mathrm{~mm}$ の $\mathrm{MgCl}_{2}$ 液滴を高さが約数 $10 \mathrm{~nm}$ から $7 \mu \mathrm{m}$ になる ように調整し，それを純鉄表面に付着させ，スーパーケルビ ンフォース顕微鏡 $(\mathrm{SKFM})$ を用いて液滴付着部の電位分布 を測定した ${ }^{13)}$ 。その結果，液滴の体積が小さい程，液滴付 着部に打けるノードとカソードの分離が遅く, アノードと カソード領域は小さく，しかもカソード領域に対するアノー ド領域の比率が低下することを確認している。一般に，腐食 反応は液滴中心部のアノード領域から始まり，時間の経過に 伴ってその領域が減少し，最後は全表面が腐食生成物で覆わ れてくる，このような液滴の寸法は, 本研究でのマクロな液 滴とミクロな液滴の間であり，その体積変化が主に液滴高さ の変化によるもので，しかも液滴の成分が本研究のような硫 酸とは異なるので, 直接比較はできないが，液滴の体積が小 さい程腐食速度が小さくなるのは，本研究の場合と同様であ る. 本研究におけるミクロな液滴の場合には, 同じ様にア ノードとカソードの分離が困難であると考えられる．この理 由を Fig. 12 でもって説明する.すなわち，水溶液による腐 食反応は電気化学反応の一種であり，それが進行すると，必 ずカソード領域での水素発生(または酸素消費)などの還元反 応抢よびアノード領域での金属溶解の酸化反応が伴ってく る.このようなアノードとカソードの分離・分布状態は鉄の 腐食速度を左右する重要な因子である。水溶液中 (またはマ クロな液滴)による腐食の場合, 結晶粒ごとに原子配列が異 なり，結晶粒界，空孔および成分の偏析などによって固/液 界面状態(電位)でのバラツキも大きいので，各部分をアノー ドとカソードに分離しやすいものと考えられる，その結果と して，Feの腐食速度は大きく，アノード領域での腐食痕や 結晶粒界などが現れる。, 一方, 液滴の寸法は急にミリサイズ

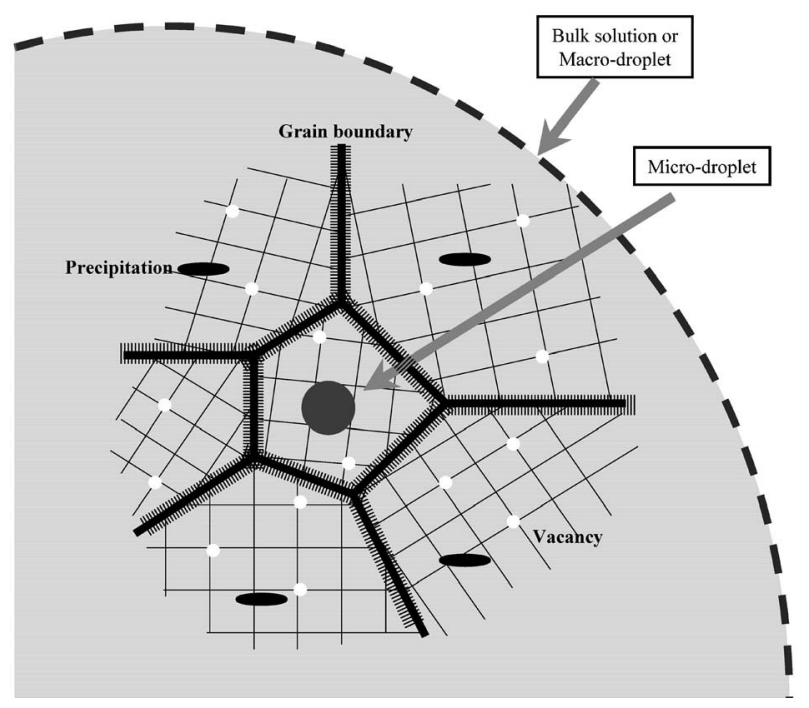

Fig. 12 Relation between formation of anode and cathode area beneath different size of $\mathrm{H}_{2} \mathrm{SO}_{4}$ solution.
からマイクロメートルおよびそれより小さい液滴へとより小 さくなる場合, またはミクロな液滴が小さい程, 固/液界面 の面積が小さくなって，そこでの界面状態(電位)のバラッキ がきわめて小さくなり, アノードとカソードが現れにくくな り，腐食の進行が遅くなったものと考えられる.

\section{4. 結 言}

純鉄の腐食速度（腐食時間：0.6 ks）がその表面に付着した 硫酸水溶液量の多少 (水溶液中，マクロな液滴およびミクロ な液滴)によってどのように影響されるかを，ポテンショス タット，デジタルマイクロスコープ $(\mathrm{DM})$ および原子間力顕 微鏡 $(\mathrm{AFM})$ を用いて調べた。得られた結果は以下の通りで ある。

（1）原子間力顕微鏡 $(\mathrm{AFM})$ のカンチレバーを用いること によって，あらかじめ決めておいた材料表面に直径 $1 \sim 10$ $\mu \mathrm{m}$ のミクロな硫酸液滴を付着させることができる．さらに $\mathrm{AFM}$ の AC ノンコンタクトモードおよびコンタクトモード を併用すると，液滴による材料表面の腐食挙動を調べること ができる。

（2）水溶液中の純鉄の腐食速度は，ミクロな液滴によるそ れより高い.

（3）ミクロな硫酸液滴による腐食速度は，液滴の体積が小 さい程小さい。大気湿度 $50 \sim 70 \% \mathrm{RH}$ の場合に比べて湿度 25 30\% RH の場合では，腐食反応の生成によって液滴が早 めに固まる。

本研究の一部は「文部科学省ハイテク・リサーチ・セン ター整備事業(平成 16 年度〜)」抢よび「科学研究費補助金 （基盤研究 $(\mathrm{C})$, 課題番号 18560093）」の助成を受けて行っ た。ここに記して謝意を表す。

\section{文献}

1) Y. Chonan et al:: Collected Abstracts of the 2005 Spring (Autumn) Meeting of the Japan Inst. Metals (2005) pp. 128-129.

2) M. Yamashita and H. Nagano: J. Japan Inst. Metals 61 (1997) 721-726.

3) N. Nishikata, Y. Ichihara and T. Tsuru: Electrochimi. Acta 41 (1996) 1057-1062.

4) H. Katayama, K. Noda, M. Yamamoto and T. Kodama: J. Japan Inst. Metals 65 (2001) 298-302.

5) J. Hu, X. D. Xiao and M. Salmeron: Appl. Phys. Lett. 67 (1995) 476-478.

6) H. Masuda: J. Japan Inst. Metals 62 (1998) 140-144.

7) H. Masuda: J. Japan Inst. Metals 62 (1998) 173-180.

8) R. Wang, L. Cong and M. Kido: Applied Surface Science $191(2002) 74-84$.

9) R. Wang, M. Kido and N. Morihiro: Mater. Trans. 44(2003) 389-395.

10) R. Wang and M. Kido: Mater. Lett. 57 (2003) 2360-2365.

11) R. Wang: Appl. Surf. Sci. 227 (2003) 399-409.

12) J. H. Perry, W. S. Calcott (Eds.): Chemical Engineers' Handbook, (McGrow-Hill Book Co., Inc., 1943) p. 346.

13) H. Masuda: Corrosion 57 (2001) 99-109.

14) M. Chikazawa and K. Tajima: Interface Chemistry, (Maruzen, 2001) pp. 1-2.

15) T. Yamazaki, A. Nishikata and T. Tsuru: Zairyo-to-Kankyo 50 (2001) 30-33. 